\title{
Peningkatan Ketrampilan Pramuka Sleman dalam Budidaya Pertanian Lahan Sempit
}

\author{
Lis Noer Aini* dan Gunawan Budiyanto \\ Program Studi Agroteknologi, Fakultas Pertanian Universitas Muhammadiyah Yogyakarta \\ Jl. Brawijaya Tamantirto Kasihan Bantul DIY 551830274-387656 \\ Email: nenny@umy.ac.id \\ DOI: $10.18196 / p p m .34 .76$
}

\begin{abstract}
Abstrak
Pramuka merupakan organisasi untuk generasi muda yang mendidik para anggotanya dengan berbagai jenis keterampilan, disiplin, kepercayaan pada diri sendiri, saling tolong-menolong, dan lain sebagainya. Salah satu tujuan dari Gerakan Pramuka adalah untuk menggali potensi dan meningkatkan keterampilan generasi muda sehingga menjadi individu yang bermanfaat bagi masyarakat dan negara. Pandemi Covid-19 yang melanda Indonesia telah menyebabkan kegiatan kepramukaan terhenti. Hal tersebut menyebabkan pembina pramuka non-ASN juga kehilangan pendapatan. Pengabdian masyarakat ini bertujuan untuk memberikan keterampilan bagi pembina pramuka non-ASN dalam rangka memanfaatkan lahan sempit untuk budidaya pertanian guna mendapatkan penghasilan. Metode yang digunakan dalam kegiatan ini adalah penyuluhan, kunjungan lapangan, dan praktik budi daya tanaman, dan budi daya ayam kampung. Penyuluhan diikuti oleh 26 pembina Pramuka dan 4 orang utusan Saka Tarunabumi. Hasil yang diperoleh menunjukkan bahwa sebagian pembina Pramuka belum mengetahui cara budidaya tanaman dan ternak di lahan sempit. Setelah kegiatan pengabdian masyarakat dilakukan, terdapat 6 orang pembina yang melakukan budi daya ayam kampung untuk tahap pembibitan (penyediaan bibit ayam kampung) dan pembesaran ayama kampung dan7 orang melakukan budi daya tanaman pada lahan sempit. Sementara peserta yang lain sedang mempersiapkan untuk melakukan budi daya tanaman dan ternak.
\end{abstract}

Kata Kunci: Pramuka, penghasilan, tanaman, ternak

\section{Pendahuluan}

Gerakan Pramuka merupakan organisasi pendidikan nonformal yang menjadi wadah dalam melaksanakan pendidikan kepanduan yang dilaksanakan di Indonesia. Salah satu tujuan dari Gerakan Pramuka adalah untuk menggali potensi dan meningkatkan keterampilan generasi muda sehingga menjadi individu yang bermanfaat bagi masyarakat dan negara (Pusdiklat Pramuka, 2019). Ujung tombak dari kegiatan kepramukaan adalah pembina pramuka yang mendampingi semua kegiatan kepramukaan dalam berbagai tingkat. Pandemi Covid-19 telah memberikan dampak terhadap kegiatan kepramukaan. Permasalahan utama tidak terselenggaranya kegiatan kepramukaan secara offline adalah pembina pramuka nonpegawai tidak mendapatkan penghasilan karena kegiatan membina merupakan penghasilan utama bagi mereka.

Potensi pengembangan kemampuan pembina Pramuka dapat dilakukan melalui peningkatan kemampuan untuk budi daya pertanian pada lahan sempit. Pilihan budi daya pertanian pada lahan sempit dilakukan karena tren saat ini, yakni lahan yang dapat digunakan untuk budi daya tidak luas. Namun demikian, hal ini mampu meningkatkan ekonomi dan kemampuan sosial yang dapat ditularkan kepada masyarakat. Budi daya pertanian pada lahan sempit dapat dilakukan melalui teknik budi daya vertikultur dan hidroponik dan budi daya ternak, salah satunya budi daya ayam KUB.

Vertikultur adalah teknik budi daya tanaman secara vertikal sehingga budi daya tanaman dilakukan secara bertingkat. Teknik budi daya ini tidak memerlukan lahan yang luas dengan komoditas yang beragam, terutama tanaman hortikultura (Kusmiati dan Solikhah, 2015; Mariyam, et al., 2018). Selain sistem vertikultur, budi daya tanaman pada lahan sempit dapat dipadukan secara hidroponik. Hidroponik merupakan budidaya pertanian tanpa menggunakan media tanah, tetapi menggunakan air sebagai media tanam (Roidah, 2014; Rakhman, et al., 2015). Sistem budi daya menggunakan vertikultur dan hidroponik ini selain 
meningkatkan produktivitas pekarangan juga dapat memberikan nilai estetika pada lahan sempit. Budi daya lain yang dapat dilakukan pada lahan sempit adalah budi daya ayam KUB. Ayam KUB merupakan ayam kampung unggulan dengan potensi ekonomi tinggi. Budi daya ayam tersebut dapat dilakukan secara bertahap, meliputi tahap pembibitan, pembesaran, dan penyiapan indukan. Keterampilan budi daya pertanian pada lahan sempit dapat menjadi sumber pendapatan bagi pembina pramuka yang terdampak Covid-19.

\section{Metode Pelaksanaan}

Metode pengabdian kepada masyarakat bersifat partisipatif yang dilaksanakan melalui penyuluhan, kunjungan lapangan, dan pelatihan. Pemilihan metode dengan penyuluhan dilakukan untuk memberikan pemahaman bagi pembina pramuka dalam rangka peningkatan produktivitas pembina. Pelatihan dilakukan untuk memberikan pengalaman dan memberikan semangat untuk dapat melaksanakan kegiatan yang akan dipilih. Alat yang digunakan untuk pelatihan adalah paralon, bor, rangka besi, pompa air mini, dan bambu. Sementara bahan yang digunakan adalah bibit tanaman dan DOC (Day Old Chicken) ayam KUB (Kampung Unggulan Balitnak). Pemilihan responden dilakukan secara purposive, yaitu peserta yang mengikuti kegiatan ini adalah pembina pramuka non-ASN di lingkungan Kwartir Cabang Sleman sebanyak 25 peserta. Pemilihan peserta dilakukan dengan mengidentifikasi status pembina Pramuka yang terdaftar pada basis data pembina Pramuka. Pengumpulan data dilakukan dengan mengidentifikasi peserta yang melakukan kegiatan budi daya, baik tanaman maupun ternak, kemudian dianalisis secara deskriptif. Tindak lanjut kegiatan dilakukan dengan pendampingan terhadap peserta yang telah mengikuti kegiatan.

\section{Hasil dan Pembahasan}

Pengabdian kepada masyarakat dilaksanakan di Kwartir Cabang Gerakan Pramuka Kabupaten Sleman dengan sasaran pembina Pramuka non-ASN. Pelaksanaan kegiatan ini dilakukan dalam lima tahap, yaitu persiapan, penyuluhan, praktik dan kunjungan lapangan, pendampingan, dan pelaporan.

1. Persiapan

Tahap persiapan pengabdian kepada masyarakat diawali dengan identifikasi pembina Pramuka non-ASN yang terdampak Covid-19 melalui kerja sama dengan Kwartir Cabang Sleman c.q. Gugus Darma, Pandu Sembada. Sosialisasi dilakukan oleh pihak Kwartir Cabang Sleman untuk mendapatkan data pembina Pramuka yang dapat dilibatkan dalam kegiatan ini. Dari data yang diperoleh, dipilih tiga puluh peserta yang berasal dari unsur pembina Pramuka dan perwakilan Satuan Karya Tarunabumi yang menjadi induk kegiatan pertanian dan peternakan di kegiatan kepramukaan.

2. Penyuluhan

Penyuluhan dilakukan dalam dua materi, yaitu budi daya tanaman pada lahan sempit dan budi daya ayam KUB. Penyuluhan diikuti oleh 30 peserta, yang terdiri atas 26 orang pembina Pramuka non-ASN dan 4 orang utusan dari Satuan Karya Tarunabumi. Pelaksanaan penyuluhan tersaji pada Gambar 1. 

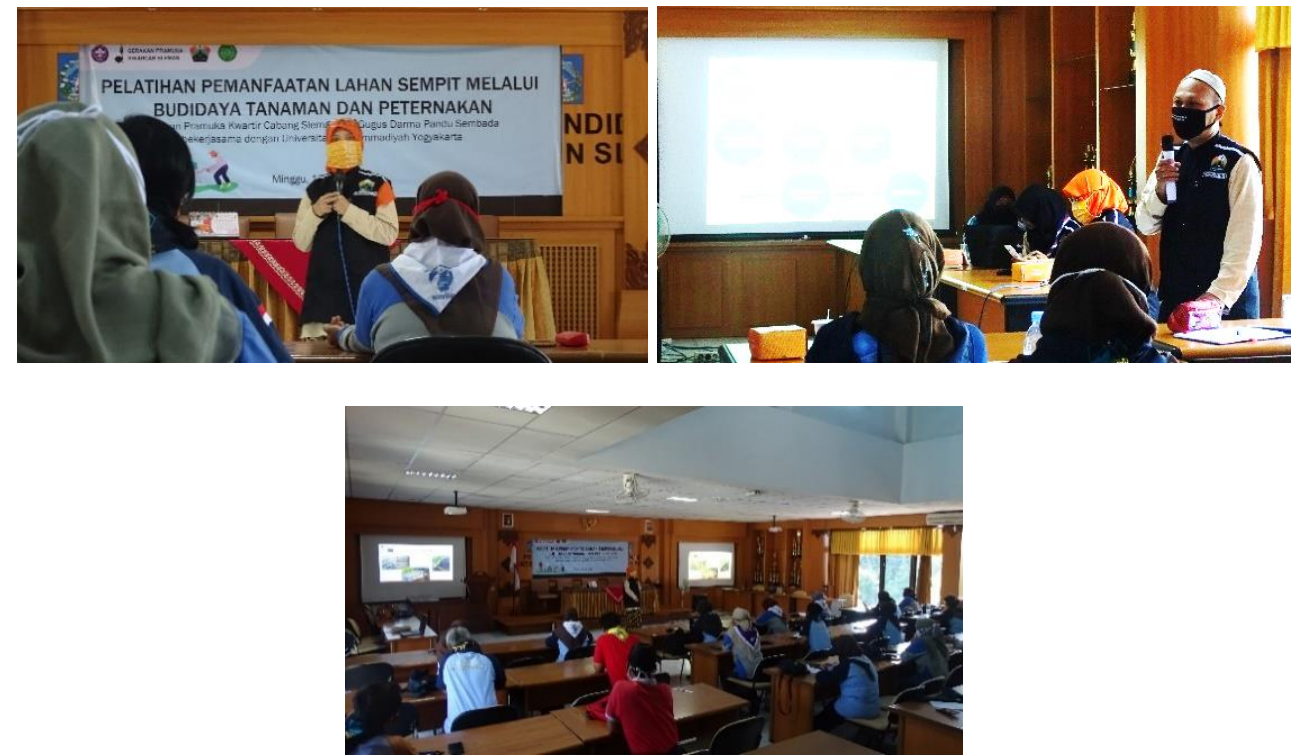

Gambar 1. Kegiatan Penyuluhan

Pelaksanaan kegiatan penyuluhan dilaksanakan dengan protokol kesehatan. Pelaksanaan kegiatan dilaksanakan di Kantor Dinas Pendidikan Kabupaten Sleman. Berdasarkan hasil diskusi dengan peserta, kegiatan penyuluhan tersebut membuka wawasan peserta untuk membuka peluang usaha di tengah pandemi Covid-19. Teknik budi daya tanaman di lahan sempit juga memberikan ide pemenuhan kebutuhan hidup selain dapat dikembangkan untuk usaha.

\section{Praktik dan kunjungan lapangan}

Pada kegiatan pengabdian kepada masyarakat ini, pengetahuan dan keingintahuan peserta kegiatan dipenuhi dengan penyuluhan, praktik, dan kunjungan lapangan. Praktik atau pelatihan dilakukan terhadap budi daya tanaman pada lahan sempit dengan menggunakan teknik vertikultur dan hidroponik. Pada kegiatan budi daya ayam kampung, dilakukan kunjungan ke peternak ayam untuk memberikan motivasi bagi peserta.

Praktik budi daya tanaman secara vertikultur dan hidroponik dilaksanakan di Kantor Kwartir Cabang Sleman yang mempunyai lahan cukup luas untuk melaksanakan kegiatan sesuai protokol ksehatan. Hasil pelatihan yang dilakukan tersaji pada Gambar 2. Hasil pelatihan, penanaman sayur secara vertikultur dan hidroponik terlaksana dan menghasilkan sayur dengan pertumbuhan yang cukup bagus. Hal tersebut menumbuhkan minat dari peserta untuk dapat melakukan sendiri dengan menggunakan media yang mereka punyai sendiri.
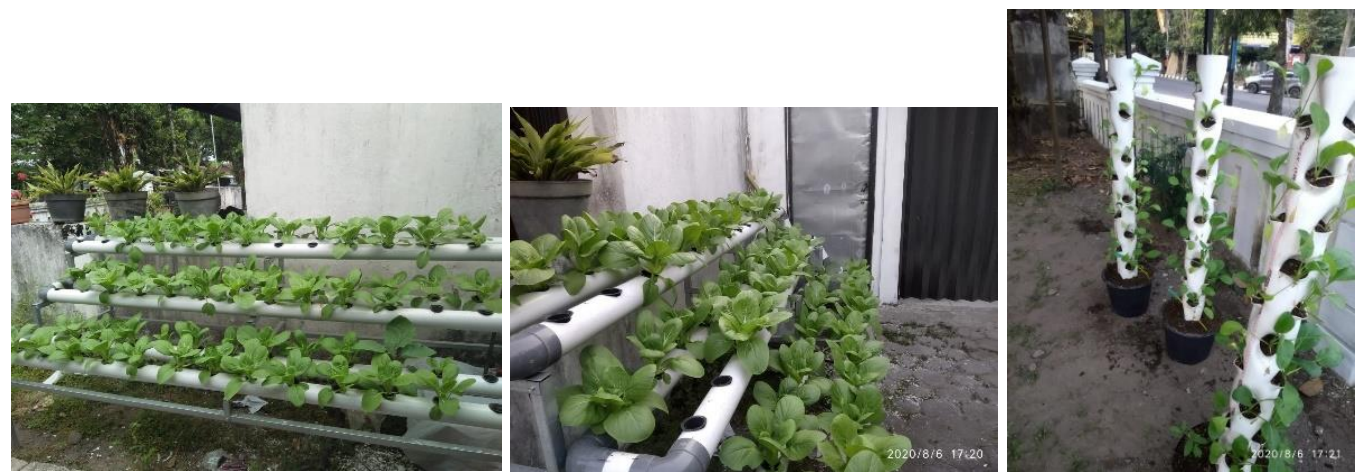

Gambar 2. Hasil Praktek Hidroponik dan Vertikultur 
Sementara kegiatan kunjungan lapangan dilakukan di peternak ayam KUB yang sekaligus pegiat budi daya pekarangan. Kegiatan kunjungan lapangan dapat dilihat pada Gambar 3.
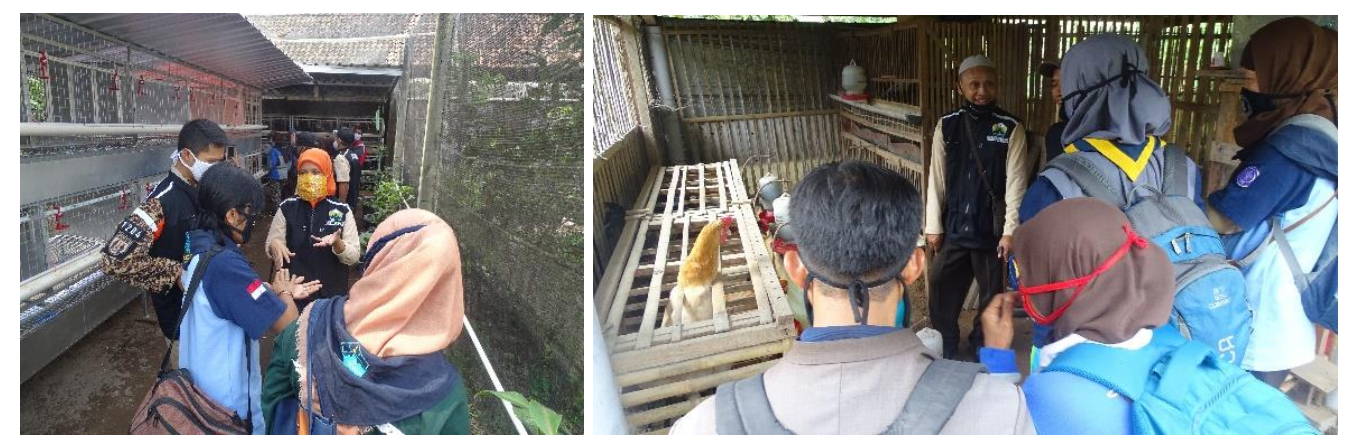

Gambar 3. Kunjungan lapangan

Pada hasil kunjungan lapangan, sebagian peserta sangat antusias mengikuti kegiatan kunjungan lapangan. Hal ini ditunjukkan dengan diskusi yang dilakukan. Kunjungan ke peternak ayam yang sudah sukses melakukan budi daya tanaman KUB membuat sebagian peserta tertarik untuk melakukan budi daya ayam KUB. Di sisi lain, karena lokasi kunjungan juga merupakan pegiat budi daya pekarangan, sebagian peserta berminat untuk melakukan intensifikasi pekarangan melalui budi daya buah dan sayur.

\section{Pendampingan}

Kegiatan pendampingan dilakukan terhadap peserta pelatihan yang melakukan kegiatan lanjutan dari yang diperoleh sebelumnya. Pendampingan dilaksanakan terhadap 6 peternak ayam KUB dan 7 pembudi daya pekarangan pemula hasil pelatihan. Hasil pendampingan terhadap budi daya lahan sempit disajikan pada Gambar 4. Sementara hasil pendampingan budi daya ayam KUB disajikan pada Gambar 5. Budi daya pekarangan dilakukan dengan memanfaatkan bahan tidak terpakai, sedangkan budidaya tanaman dilakukan dengan menggunakan polybag. Budi daya pekarangan dilakukan terhadap komoditas hortikultura, terutama sayuran. Teknik budi daya secara hidroponik belum dilakukan karena dianggap memerlukan biaya yang cukup besar untuk melakukan perakitan instalasi hidroponik. Budi daya tanaman dengan memanfaatkan benda yang sudah tidak terpakai dianggap lebih menguntungkan untuk dilakukan dan lebih bermanfaat karena dapat mengurangi limbah.

Pendampingan terhadap budi daya ayam KUB dilakukan dengan menyediakan DOC yang dapat dikembangkan oleh peserta yang berminat. Dari COD yang diberikan kepada peserta yang berminat mengembangkan, diharapkan sebagian dapat dijadikan indukan dan sebagian yang lain dapat dilakukan pembesaran dan dijual sebagai ayam pedaging. Dalam pengembangannya, diharapkan nantinya dapat menyediakan telur dan daging ayam kampung. Dari hasil budi daya yang dilakukan, terdapat ayam yang sudah siap jual dengan berat sekitar $1 \mathrm{~kg}$. 

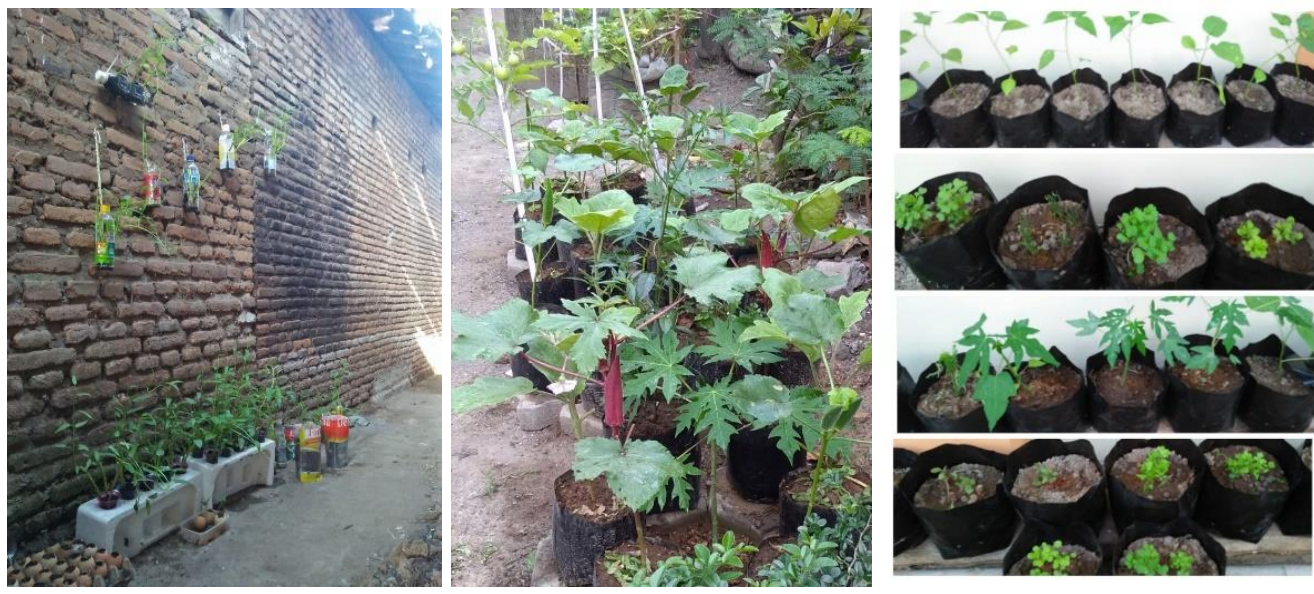

Gambar 4. Hasil pendampingan budidaya tanaman pada lahan sempit
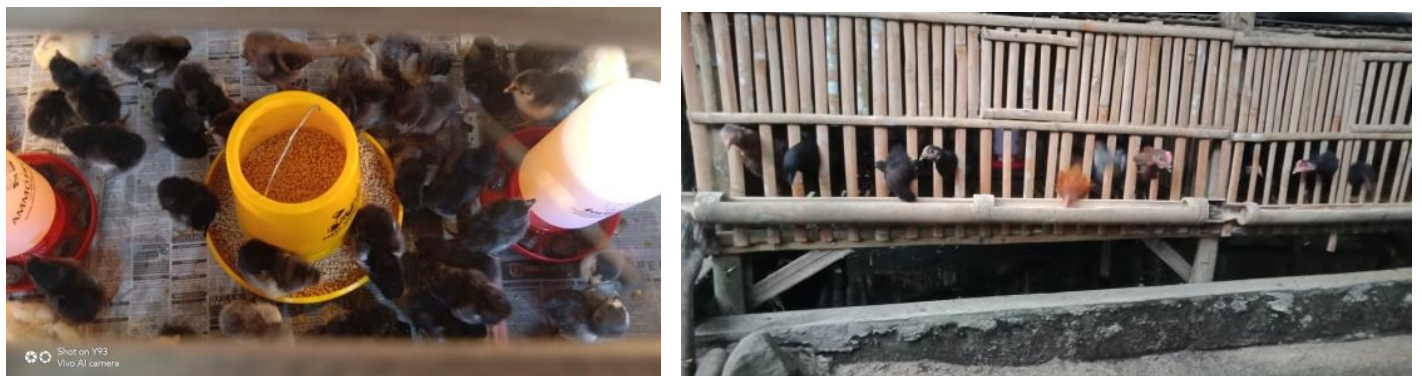

Gambar 5. Hasil pendampingan budidaya ayam KUB

\section{Simpulan}

Berdasarkan hasil pelatihan dan pendampingan budi daya pertanian lahan sempit, pengabdian masyarakat yang dilakukan berjalan dengan baik. Terdapat 6 orang yang melakukan budi daya ayam KUB dan 7 orang yang melakukan budi daya lahan sempit. Hasil yang diperoleh adalah budi daya tanaman sayur menggunakan polybag ataupun barang yang sudah tidak terpakai. Dari pendampingan terhadap budi daya ayam KUB, telah diperoleh ayam yang siap jual dengan berat $1 \mathrm{~kg}$.

\section{Ucapan Terima Kasih}

Terima kasih kami sampaikan kepada:

1. Universitas Muhammadiyah Yogyakarta melalui LP3M yang telah memberikan pendanaan pelaksanaan pengabdian kepada masyarakat.

2. Kwartir Cabang Sleman yang telah memfasilitasi terlaksananya kegiatan.

3. Dewan Kerja Cabang Sleman yang telah menjadi tim pelaksana kegiatan.

\section{Daftar Pustaka}

[KBBI] Kamus Besar bahasa Indonesia. 2019. Arti Gerakan Pramuka. https://kbbi.web.id/. Akses 1 September 2019.

Kusmiati, A dan U. Solikhah, 2015. Peningkatan Pendapatan Keluarga Melalui Pemanfaatan Pekarangan Rumah Dengan Menggunakan Teknik Vertikultur. Asian Journal of Innovation and Entrepreneurship. Vol 4, No. 2: 94-101. DOI: https://doi.org/10.20885/ajie.vol4.iss2.art4 
Maryam, S., T. Rahayu, Budiwati, D.O. Widiastuti, A.P. Sari, N.P. Rini, A.I. Astuti. 2013. Implementasi Eco-education di Sekolah Perkotaan Melalui Budidaya Vertikultur Tanaman Hortikultura Organik. Lembaga Pengabdian Kepada Masyarakat. Universitas Negeri Yogyakarta.

[Pusdiklat] Pusat Pendidikan dan Latihan Pramuka. 2019. Pramuka - Gerakan Pramuka. http://www.pusdiklat.web.id/id3/471368/Pramuka_30759_pusdiklat.html\#Tujuan_Gerakan_Pramuka. Akses 1 September 2019.

Rakhman, A., Lanya, B., Rosadi, R.A. Bustomi, K., Zen, M., 2015. Pertumbuhan Tanaman Sawi Menggunakan Sistem Hidroponik Dan Akuaponik. Jurnal Teknik Pertanian Lampung,Vol.4, No.4 : 245-254

Roidah, I.S. 2014. Pemanfaatan Lahan Dengan Menggunakan Sistem Hidroponik. Jurnal Universitas Tulungagung BONOROWO Vol. 1.No.2: 43-50. 